This Accepted Author Manuscript is copyrighted and published by Elsevier. It is posted here by agreement between Elsevier and University of Brasilia. Changes resulting from the publishing process - such as editing, corrections, structural formatting, and other quality control mechanisms - may not be reflected in this version of the text. The definitive version of the text was subsequently published in [Theriogenology, Volume Volume 57, Issue 5, 15 March 2002, Pages 1467-1483, doi:10.1016/S0093-691X(02)00641-6].You may download, copy and otherwise use the AAM for non-commercial purposes provided that your license is limited by the following restrictions:

(1) You may use this AAM for non-commercial purposes only under the terms of the CC-BY-NCND license.

(2) The integrity of the work and identification of the author, copyright owner, and publisher must be preserved in any copy.

(3) You must attribute this AAM in the following format: [agreed attribution language, including link to CC BY-NC-ND license + Digital Object Identifier link to the published journal article on Elsevier's ScienceDirect ${ }^{\circledR}$ platform].

Este Manuscrito do Autor Aceito para Publicação (AAM) é protegido por direitos autorais e publicado pela Elsevier. Ele esta disponível neste Repositório, por acordo entre a Elsevier e a Universidade de Brasília. As alterações decorrentes do processo de publicação - como a edição, correção, formatação estrutural, e outros mecanismos de controle de qualidade - não estão refletidas nesta versão do texto. A versão definitiva do texto foi posteriormente publicado em [Theriogenology, Volume 57, Número 5, 15 de Março de 2002, Páginas 1467-1483, doi:10.1016/S0093-691X(02)00641-6]. Você pode baixar, copiar e utilizar de outra forma o AAM para fins não comerciais, desde que sua licença seja limitada pelas seguintes restrições:

(1) Você pode usar este AAM para fins não comerciais apenas sob os termos da licença CC- BYNC-ND.

(2) A integridade do trabalho e identificação do autor, detentor dos direitos autorais e editor deve ser preservado em qualquer cópia.

(3) Tem de atribuir este AAM no seguinte formato: [acordo na linguagem atribuída, incluindo o link para CC BY-NC-ND licença Digital + DOI do artigo publicado na revista Elsevier ScienceDirect ${ }^{\circledR}$ da plataforma]. 


\title{
Zebu (Bos indicus) ovarian preantral follicles: morphological characterization and development of an efficient isolation method
}

\author{
Carolina Madeira Lucci \\ Rodolfo Rumpf \\ José Ricardo Figueiredo \\ Sônia Nair Báo
}

\section{Abstract}

Preantral follicles are a major source of oocytes, and their utilization as an important tool to store large number of female gametes for future use in reproductive programs has been investigated. The increasing importance of studies in this subject, together with the important role of Zebu cattle in the economy of tropical and subtropical countries as well as their well-known differences from European cattle, led to this research. The present study aims to determine the best size interval for sectioning ovarian tissue to isolate preantral follicles from Zebu cows using a tissue chopper and to evaluate the follicular quality after isolation. Furthermore, it aims to provide information about the Zebu cow preantral follicle population and use this data (as a control) to evaluate the effectiveness of the tested isolation method. Testing eight different tissue sectioning size intervals, it was possible to conclude that the $125-\mu \mathrm{m}$-section interval is shown to be better than the intervals of 25,50 , 175 and $200 \mu \mathrm{m}$ to isolate preantral follicles from Zebu cow ovaries. The 125$\mu \mathrm{m}$ interval allowed the recovery of $26,050 \pm 1611$ (mean \pm S.E.M.) preantral follicles per one-half ovary, while the number of preantral follicles in situ estimated by evaluation of histological sections was $35,288 \pm 2342$ per one-half ovary. Thus, the mean ( \pm S.E.M.) recovery rate (=[number of preantral follicles isolated/number of preantral follicles in situ in the same ovary] $\times 100$ ) was $74.3 \pm 4.3 \%$. The morphometrical analysis showed that Bos indicus preantral follicles are similar to B. taurus preantral follicles based on previous reports. In conclusion, this study showed that a simple, mechanical method can be used effectively to isolate a large number of intact preantral follicles from Zebu cow ovaries, with a high recovery rate.

Keywords: Zebu cow; Preantral follicles; Isolation; Follicle quality; Ultrastructure 


\section{Introduction}

In the past few decades, a great amount of research has addressed the importance of studying ovarian preantral follicles for future utilization in reproductive programs. As these follicles account for the vast majority of follicles $(90 \%)$ in the ovary [1], they can provide a great number of potentially viable oocytes for the in vitro reproductive techniques, such as IVF and cloning. To reach this goal, however, it is important to isolate these follicles from the ovary, otherwise, they will naturally and invariably die by atresia [1].

The most important characteristic of an isolation method is to rescue a large number of follicles without causing damage to their structure. Indeed, one of the most efficient methods for isolating a large number of follicles consists of using a tissue chopper [2-4]. Recently, however, studies have demonstrated that the best interval for sectioning the ovarian tissue using the tissue chopper can vary according to species $[5,6]$. In addition to isolating a large number of follicles, a suitable method should preserve the normal follicular morphology after isolation, not only on the structural level, but also on the ultrastructural level [7]. The maintenance of follicular quality after isolation is extremely important and should be investigated, because structural or ultrastructural damages can significantly affect further in vitro growth and maturation of oocytes within preantral follicles [8].

In spite of the fact that there is a lot of literature concerning European bovine preantral follicles, almost nothing is known about this area in Zebu cattle. Actually, Zebu bovine (Bos indicus) differ from European bovine (B. taurus) in several aspects related to reproduction [9-14], and therefore, it is important to start studying the preantral follicle population in this bovine genotype.

The present study aims to determine the best size interval for sectioning the ovarian tissue to isolate preantral follicles from Zebu cows using a tissue chopper and to evaluate the follicular quality after isolation. Furthermore, it aims to provide information about the preantral follicle population in Zebu cows, and use this data (as a control) to evaluate the effectiveness of the studied isolation method.

\section{Materials and methods}

\subsection{Ovaries}

A total of 12 ovaries from 12 nonpregnant adult Zebu cows (Nelore) were used in this study, six per experiment. All the ovaries were collected at a local slaughterhouse and transported to the laboratory within 1-3 h. During transport, the ovaries were stored in a thermos flask filled with PBS kept at $32-34^{\circ} \mathrm{C}$.

\subsection{Experiment 1: isolation of preantral follicles}

Eight treatments were tested differing from each other according to the cut interval $(\mu \mathrm{m})$ adjusted in the tissue chopper (Fig. 1; The Mickle Laboratory Engineering Co., Gomshal, 


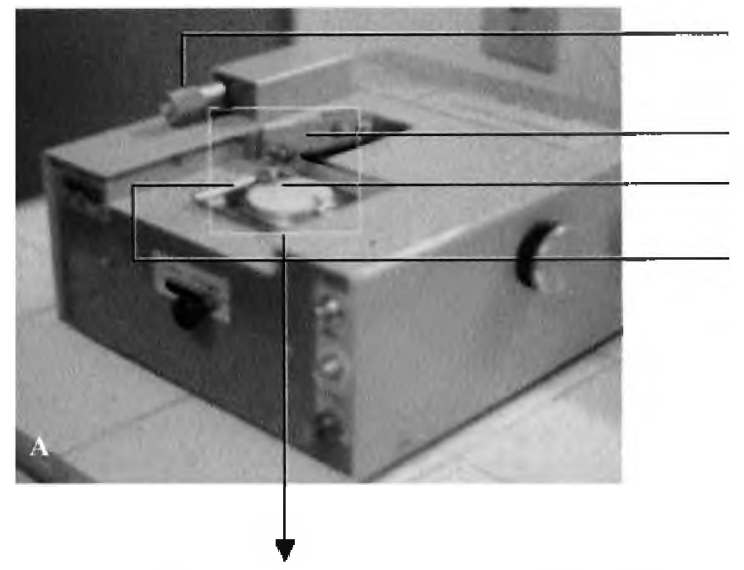

Sections interval adjustment button

Cutting arm with blade

Rotating Disk

Mobile Plate
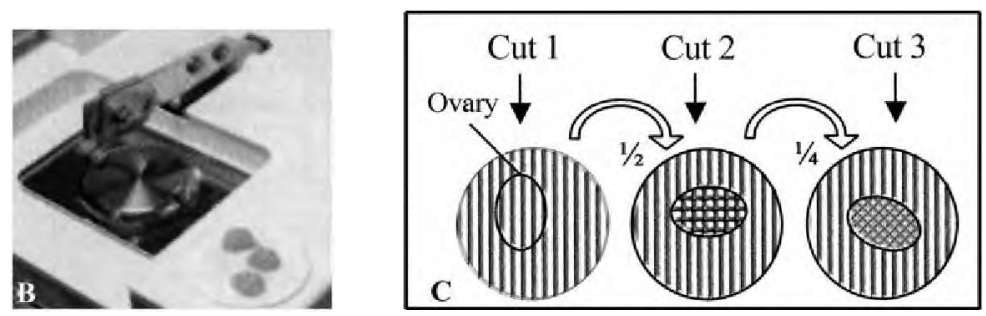

Fig. 1. (A) The tissue chopper in a panoramic view, and (B) a close up of the cutting arm, the mobile plate and the rotating disk. After setting the section interval parameters and turning on the equipment, the plate moves accordingly from left to right while the cutting arm makes rapid up-and-down movements. (C) A diagram of the longitudinal (cut 1), transverse (cut 2) and oblique (cut 3) cuts made to produce very small and relatively uniform-sized ovarian fragments.

Surrey, UK): 25 (T1), 50 (T2), 75 (T3), 100 (T4), 125 (T5), 150 (T6), 175 (T7), and $200 \mu \mathrm{m}$ (T8). To simultaneously test all the treatments, each ovary was divided into eight equal parts that were randomly distributed to the eight test treatments. In all treatments, the tissue chopper cut the ovarian tissue from the cortical to the medullar side along the longitudinal, transverse and oblique axes, producing very small and relatively uniform-sized fragments. The ovarian fragments obtained were placed in $50 \mathrm{ml}$ of PBS plus $5 \%$ fetal calf serum (Sigma, St. Louis, MO, USA), and then suspended 20 times with a large Pasteur pipette (diameter $\sim 1600 \mu \mathrm{m}$ ) and 20 times with a smaller Pasteur pipette (diameter $\sim 600 \mu \mathrm{m}$ ). The suspensions were separately filtered through 500 and $100 \mu \mathrm{m}$ Nylon mesh filters (Fig. 2). Each treatment was repeated six times.

To estimate the number of isolated preantral follicles per treatment, the tubes containing the suspension were gently inverted several times to disperse the follicles. Then, two samples of $1 \mathrm{ml}$ each were taken from each tube and examined separately under a phase contrast inverted microscope (Zeiss Axiovert, Jena, Germany).

The isolated preantral follicles were classified into three developmental stages by their morphological appearance according to Hulshof et al. [15], i.e. primordial follicles are oocytes surrounded by one layer of flattened or flattened-cubical granulosa cells; primary 

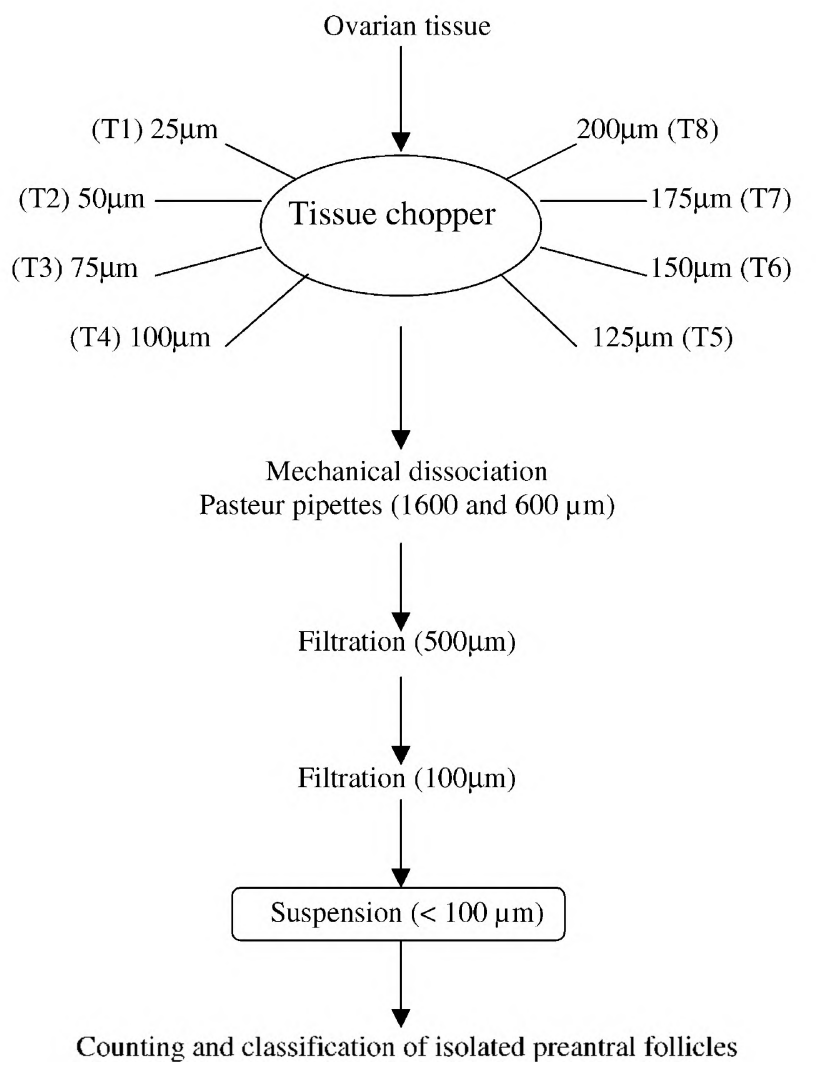

Fig. 2. Experimental protocol to test different interval of serial sections in the tissue chopper to isolate preantral follicles from Zebu cow ovaries.

follicles have a single layer of cubical granulosa cells, and secondary follicles are oocytes surrounded by two or more layers of cubical granulosa cells.

\subsection{Experiment 2: qualitative and quantitative analysis of the specific method}

To evaluate quantitatively and qualitatively, the efficiency of the mechanical method for the isolation of preantral follicles, each ovary was cut longitudinally into two halves. One half was used to study the preantral follicle population in situ and the other was used to isolate preantral follicles (Fig. 3). Preantral follicles were isolated from the ovarian halves using the treatment that yielded the largest number of isolated preantral follicles, from the eight treatments tested in Experiment 1. The diameters of freshly isolated preantral follicles were measured under an inverted microscope using an ocular micrometer.

In order to estimate the preantral follicle population in Zebu cow ovaries, the ovarian halves that were not used to isolate preantral follicles were fixed in Carnoy's fixative and 


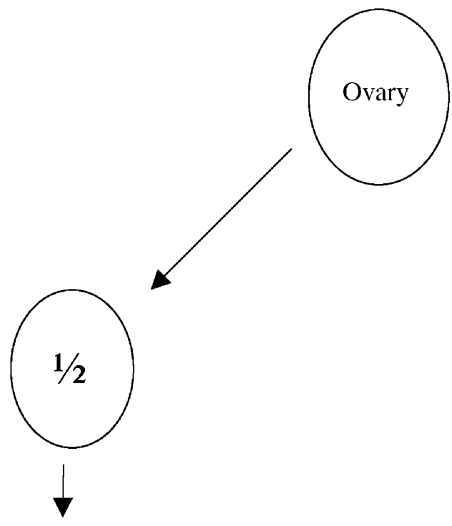

Tissue chopper - best interval

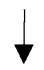

Mechanical dissociation (Pasteur pipettes - 1600 and $600 \mu \mathrm{m}$ )

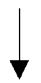

Filtration $(500$ and $100 \mu \mathrm{m})$

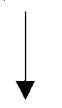

Counting and classification of isolated follicles

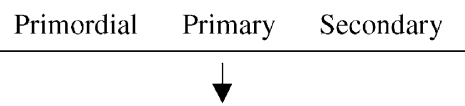

Histological evaluation

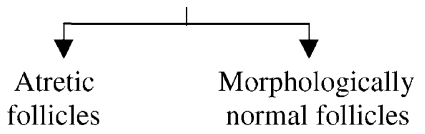

Fig. 3. Experimental protocol to study Zebu cow ovarian preantral follicles in situ and after isolation procedure.

processed for histological evaluation. The ovarian halves were serially sectioned at $7 \mu \mathrm{m}$. Every 120th section [16] was mounted and stained with periodic acid Schiff (PAS) and hematoxylin. The number of preantral follicles was estimated by counting the follicles in each section using the nucleus of the oocyte as a marker and the correction factor described by Gougeon and Chainy [17]. Preantral follicles were classified as primordial, primary and secondary according to their developmental stages and as normal or degenerate according to their morphological appearance. Follicles were classified as degenerated if they presented one or more of the following aspects: condensed oocyte nucleus, shrunken oocyte, pycnotic bodies in the granulosa cells, low cellular density or basement membrane 
breakdown. For each ovary, the recovery rate (RR) of follicles isolated by the mechanical method was calculated as follows:

$$
\text { RR per ovary }=\frac{\text { number of isolated follicles }}{\text { number of in situ follicles }} \times 100 \text {. }
$$

Sections were examined and photographed using a Zeiss Axiophot light microscope. Using an ocular micrometer, the diameters of the follicles and the oocytes in situ were determined and the granulosa cells were counted, both in the section where the nucleolus of the oocyte was observed (equatorial section).

To evaluate their quality, freshly isolated preantral follicles were prefixed in a solution containing $2 \%$ paraformaldehyde and $2.5 \%$ glutaraldehyde in $0.1 \mathrm{M}$ sodium cacodylate buffer, for $30 \mathrm{~min}$ at room temperature. Then, the follicles were embedded in drops of $200 \mu \mathrm{l}$ of $4 \%$ agar solution (agarose, type VII, Sigma, St. Louis, MO, USA). The agar drops were fixed in the same fixation solution described above for another $3 \mathrm{~h}$ at room temperature. The drops were dehydrated, embedded in paraffin wax, serially sectioned at a thickness of $7 \mu \mathrm{m}$ and stained with PAS and haematoxylin. Preantral follicles were classified as morphologically normal or degenerate as described above.

To better evaluate follicular morphology, ultrastructural analysis was performed in some isolated follicles to verify if slight damages that could not be observed at the light microscopic level were present. Small pieces of nontreated ovaries were processed as well and used as a control. Isolated follicles were prefixed and embedded in agar drops as described above. The ovarian pieces and the agar drops were fixed in a solution containing $2 \%$ paraformaldehyde and $2.5 \%$ glutaraldehyde in $0.1 \mathrm{M}$ sodium cacodylate buffer, for $3 \mathrm{~h}$ at room temperature or overnight at $4{ }^{\circ} \mathrm{C}$. After fixation, the specimens were rinsed in buffer and postfixed in a solution containing $1 \%$ osmium tetroxide, $0.8 \%$ potassium ferricyanide and $5 \mathrm{mM} \mathrm{CaCl}$ in $0.1 \mathrm{M}$ cacodylate buffer. Subsequently, the samples were dehydrated in acetone and embedded in Spurr. Thin sections $(70 \mathrm{~nm})$ were stained with uranyl acetate and lead citrate, and examined using a Jeol JEM 100C transmission electron microscope. All the organelles were carefully observed, and special attention was given to the basement membrane and the contact between oocyte and granulosa cells, where the mechanical isolation might have caused physical damage.

\subsection{Statistical analysis}

Analysis of variance and Fisher's PLSD test (StatView for Windows) were used to compare: (1) the mean number of isolated preantral follicles among treatments, (2) the mean number/percentages of preantral follicles in each class that were isolated and observed in situ and (3) the recovery rate among the three follicular classes. Data were log-transformed if Hartley's test indicated heterogeneity of variance. The diameters of preantral follicles in situ and isolated, as well as the diameters of the oocytes and the number of granulosa cells at the equatorial section in situ, were compared by Scheffe's test (StatView for Windows). The percentages of degenerated preantral follicles isolated and in situ were compared by Chi-square (BioEstat 2.0 for Windows). Values were considered statistically significant when $P<0.05$. 
Table 1

Number of isolated preantral follicles (mean \pm S.E.M.) at eight different cut intervals

\begin{tabular}{lll}
\hline Treatment $($ cut interval $(\mu \mathrm{m}))$ & \multicolumn{1}{c}{ Number of follicles per one-eighth ovary $(n=6)$} \\
\cline { 2 - 3 } & Mean \pm S.E.M. & Range \\
\hline T1 (25) & $3316 \pm 497 \mathrm{a}$ & $2079-4806$ \\
T2 $(50)$ & $3636 \pm 556 \mathrm{a}$ & $2133-5724$ \\
T3 $(75)$ & $4140 \pm 614 \mathrm{ab}$ & $621-7884$ \\
T4 $(100)$ & $5629 \pm 1118 \mathrm{ab}$ & $2403-10422$ \\
T5 $(125)$ & $6408 \pm 1137 \mathrm{~b}$ & $3024-11070$ \\
T6 $(150)$ & $5112 \pm 818 \mathrm{ab}$ & $2700-7479$ \\
T7 $(175)$ & $3757 \pm 699 \mathrm{a}$ & $1593-5967$ \\
T8 $(200)$ & $3631 \pm 375 \mathrm{a}$ & $2025-6264$ \\
\hline
\end{tabular}

Rows with different letters differ significantly $(P<0.05)$.

\section{Results}

\subsection{Isolation of ovarian preantral follicles}

Table 1 shows the outcome that the eight treatments had on the number of preantral follicles isolated per one-eighth ovary. The mechanical isolation treatment of the Zebu cow ovaries provided a large number of isolated preantral follicles, irrespective of the cut interval used. However, a large individual variation within the treatments was observed. The limits of this variation were 621 (T3) and 11,070 (T5) preantral follicles per one-eighth ovary. The mean number of isolated preantral follicles increased from $\mathrm{T} 1(25 \mu \mathrm{m})$ to $\mathrm{T} 5$ $(125 \mu \mathrm{m})$ and decreased afterwards in T6 $(150 \mu \mathrm{m}), \mathrm{T} 7(175 \mu \mathrm{m})$ and $\mathrm{T} 8(200 \mu \mathrm{m})$. However, T5 $(125 \mu \mathrm{m})$ showed a significantly $(P<0.05)$ higher number of isolated preantral follicles only when compared with T1 $(25 \mu \mathrm{m}), \mathrm{T} 2(50 \mu \mathrm{m}), \mathrm{T} 7(175 \mu \mathrm{m})$ and T8 $(200 \mu \mathrm{m})$.

\subsection{Number of preantral follicles in situ and after isolation}

Since T5 $(125 \mu \mathrm{m})$ allowed the highest number of isolated preantral follicles and was the only treatment that showed any statistical difference when compared to the others, this treatment was chosen to proceed with follicular isolation in the second experiment. Using the $125-\mu \mathrm{m}$ interval, the number (mean \pm S.E.M.) of isolated preantral follicles per onehalf ovary was $26,050 \pm 1611$ (range 23,900-30,800). The number (mean \pm S.E.M.) of preantral follicles in situ, estimated by evaluation of histological sections was $35,288 \pm 2342$ (range $29,899-39,410$ ) per one-half ovary. Thus, the mean ( \pm S.E.M.) recovery rate $(=$ [number of preantral follicles isolated/number of preantral follicles in situ in the same ovary] $\times 100$ ) was $74.3 \pm 4.3 \%$ (range $61.4-79.9 \%$ ). Overall, the number of preantral follicles in situ was significantly higher than the number of isolated preantral follicles in one-half ovary $(P<0.05)$.

The mean number of primordial, primary and secondary follicles in situ and after isolation and their corresponding proportions are shown in Table 2. Both the number and 
Table 2

Mean number and percentage of primordial, primary and secondary follicles in situ and isolated per one-half ovary of Zebu cows (mean \pm S.E.M.)

\begin{tabular}{lccc}
\hline Follicle class & \multicolumn{2}{l}{$\begin{array}{l}\text { Number and percentage of preantral follicles per one-half ovary } \\
\text { (mean } \pm \text { S.E.M. })\end{array}$} & Recovery rate \\
\cline { 2 - 4 } & In situ & lsolated & \\
\hline Primordial & $32266 \pm 1846 \mathrm{aA}(91.4 \% \pm 1.5) \mathrm{aD}$ & $25500 \pm 1602 \mathrm{bA}(98.0 \% \pm 0.9) \mathrm{bD}$ & $79.2 \pm 3.2 \mathrm{G}$ \\
Primary & $2404 \pm 652 \mathrm{aB}(6.5 \% \pm 2.4) \mathrm{aE}$ & $400 \pm 35 \mathrm{bB}(1.6 \% \pm 0.9) \mathrm{bE}$ & $20.5 \pm 5.2 \mathrm{H}$ \\
Secondary & $590 \pm 196 \mathrm{aC}(2.1 \% \pm 1.6) \mathrm{aF}$ & $150 \pm 20 \mathrm{bC}(0.4 \% \pm 0.2) \mathrm{bF}$ & $37.6 \pm 16.5 \mathrm{H}$ \\
Total & $35288 \pm 2342 \mathrm{a}(100 \%)$ & $26050 \pm 1612 \mathrm{~b}(100 \%)$ & $74.3 \pm 4.3$ \\
\hline
\end{tabular}

Columns with different letters (a, b) differ $P<0.05$. Rows with different letters $(\mathrm{A}, \mathrm{B}, \mathrm{C})$ differ $P<0.05$ (concerning number of follicles). Rows with different letters (D, E, F) differ $P<0.05$ (concerning percentage of follicles). Rows with different letters $(\mathrm{G}, \mathrm{H})$ differ (concerning recovery rate) significantly $(P<0.05)$.

the proportions of preantral follicle classes obtained after mechanical isolation were significantly different than those observed in situ $(P<0.05)$. The mean recovery rates of primordial, primary and secondary follicles were $79.2,20.5$ and $37.6 \%$, respectively (Table 2), showing that the mechanical method isolated mainly primordial follicles $(P<0.05)$.

\subsection{Morphometric analysis of preantral follicles in situ and after isolation}

Histological analysis in situ showed that primordial follicles have an oocyte surrounded by one layer of squamous or squamous-cuboidal granulosa cells; primary follicles have a single layer of cuboidal granulosa cells, and secondary follicles have an oocyte surrounded by two or more layers of cuboidal granulosa cells (Fig. 4). All the preantral follicles presented a strongly PAS positive basement membrane surrounding them. Freshly isolated

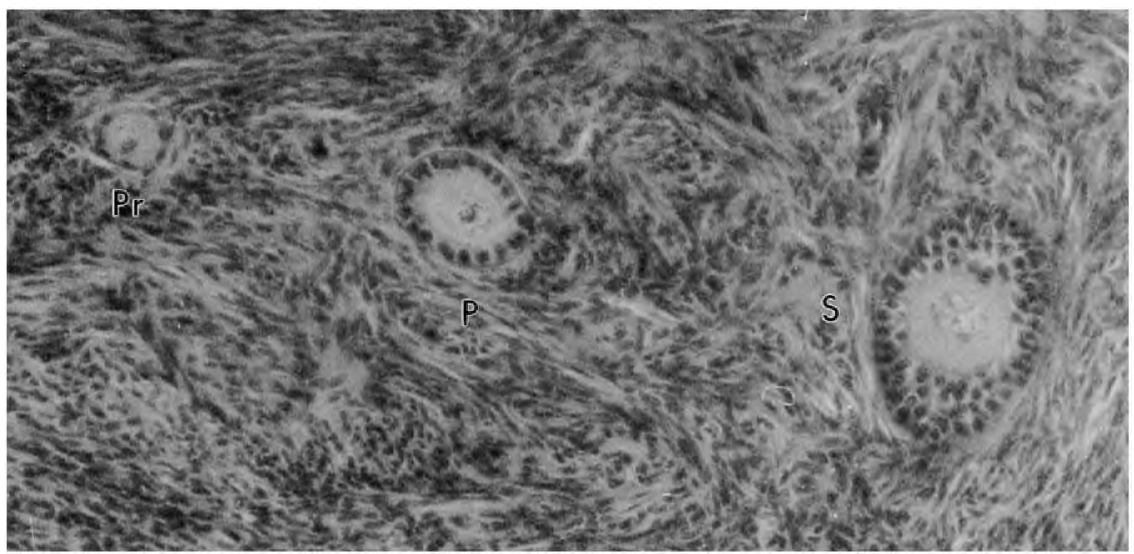

Fig. 4. Histological section of a Zebu cow ovary, showing primordial (Pr), primary (P) and secondary (S) follicles. PAS-hematoxilin stained $(255 \times)$. 


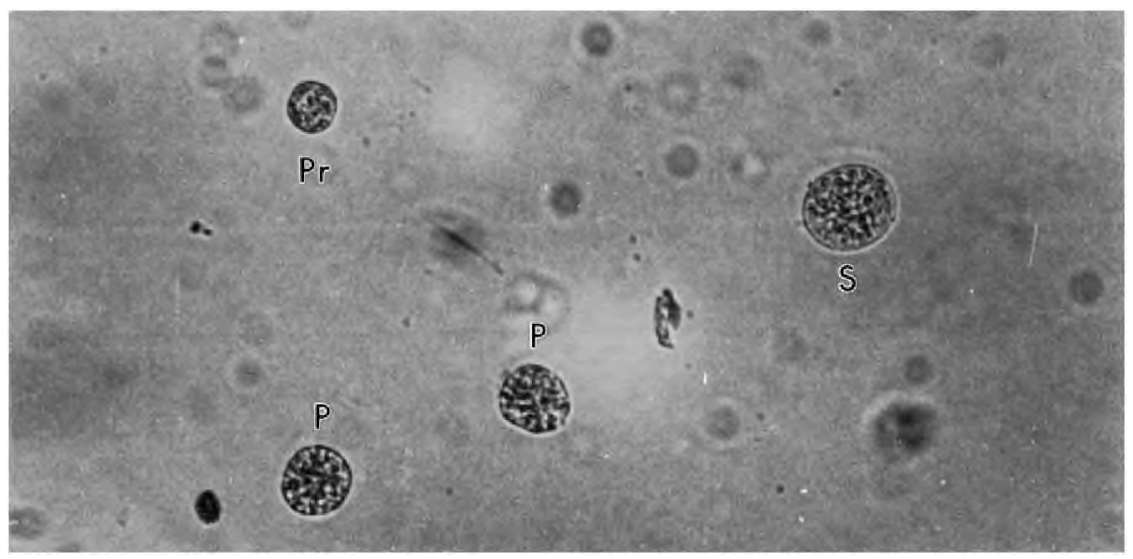

Fig. 5. Fresh mechanically isolated Zebu preantral follicles $(175 \times)$. Pr: primordial follicles; P: primary follicles; and $\mathrm{S}$ : secondary follicles.

primordial, primary, and secondary follicles in the suspension were spherical with one or more layers of granulosa cells around the oocyte, surrounded by a basement membrane (Fig. 5). After isolation, the oocytes of primary and secondary follicles were not always clearly visible because granulosa cells covered them.

Primordial, primary and secondary follicles in situ measured $36.0 \pm 0.9,48.5 \pm 1.4$ and $88.4 \pm 2.9 \mu \mathrm{m}$ in diameter, respectively, whereas after isolation they measured $22.1 \pm 0.5$, $45.5 \pm 1.4$ and $73.6 \pm 1.7 \mu \mathrm{m}$, respectively. The follicular diameters differed significantly among the three follicular classes, both in situ and after isolation $(P<0.05)$. Also, the diameters of primordial and secondary follicles were significantly lower after isolation than in situ $(P<0.05)$. As expected, the oocyte diameter in situ and the number of granulosa cells at the equatorial section differed significantly $(P<0.05)$ among follicular classes (Table 3).

Table 3

Morphometrical parameters of primordial, primary and secondary follicles after isolation and in situ (mean \pm S.E.M.)

\begin{tabular}{|c|c|c|c|c|c|c|}
\hline \multirow{2}{*}{$\begin{array}{l}\text { Follicular } \\
\text { classes }\end{array}$} & \multicolumn{2}{|c|}{ Isolated } & \multicolumn{4}{|c|}{ In situ } \\
\hline & $N$ & $\begin{array}{l}\text { Follicular } \varnothing \\
\text { (range) }\end{array}$ & $N$ & $\begin{array}{l}\text { Follicular } \varnothing \\
\text { (range) }\end{array}$ & $\begin{array}{l}\text { Oocyte } \varnothing \\
\text { (range) }\end{array}$ & $\begin{array}{l}\text { Number of } \\
\text { granulosa cells }\end{array}$ \\
\hline Primordial & 108 & $\begin{array}{l}22.1 \pm 0.5 \mathrm{Aa} \\
(15-33)\end{array}$ & 80 & $\begin{array}{l}36.0 \pm 0.9 \mathrm{bA} \\
(25-50)\end{array}$ & $\begin{array}{l}28.1 \pm 0.6 \mathrm{~A} \\
(20-35)\end{array}$ & $\begin{array}{l}7.3 \pm 0.4 \mathrm{~A} \\
(1-13)\end{array}$ \\
\hline Primary & 60 & $\begin{array}{l}45.5 \pm 1.4 \mathrm{aB} \\
(35-59)\end{array}$ & 66 & $\begin{array}{l}48.5 \pm 1.4 \mathrm{aB} \\
(35-70)\end{array}$ & $\begin{array}{l}31.7 \pm 0.7 \mathrm{~B} \\
(25-45)\end{array}$ & $\begin{array}{l}14.6 \pm 0.7 \mathrm{~B} \\
(10-29)\end{array}$ \\
\hline Secondary & 26 & $\begin{array}{l}73.6 \pm 1.7 \mathrm{aC} \\
(69-79)\end{array}$ & 33 & $\begin{array}{l}88.4 \pm 2.9 b C \\
(70-120)\end{array}$ & $\begin{array}{l}43.8 \pm 1.4 \mathrm{C} \\
(35-56)\end{array}$ & $\begin{array}{l}62.0 \pm 4.6 \mathrm{C} \\
(35-111)\end{array}$ \\
\hline
\end{tabular}

$\varnothing$ : diameter $(\mu \mathrm{m})$. Columns with different letters in loercase $(\mathrm{a}, \mathrm{b})$ differ $P<0.05$. Rows with different letters in uppercase $(\mathrm{A}, \mathrm{B}, \mathrm{C})$ differ $P<0.05$. 
Among the thousands of preantral follicles encountered in the ovarian cortex, in $83 \%$ (five/six) of the ovaries some polyovular preantral follicles (primordial and primary) could be seen. The number of oocytes within the same follicle varied between two and three. The number of polyovular preantral follicles was not expressed due to lack of parameters of calculation. In isolated follicles, it was possible to identify only two cases of polyovular follicle.

\subsection{Qualitative analysis of preantral follicles in situ and after mechanical isolation}

Freshly isolated preantral follicles appeared healthy under the inverted microscope and no denuded oocytes were observed in this study. Histological evaluation showed that, after mechanical isolation, $93.5 \%$ of preantral follicles were morphologically normal, with a healthy oocyte surrounded by one or more well-organized layers of granulosa cells without pycnotic nuclei (Fig. 6A). Histochemistry also revealed that the mechanically isolated follicles were surrounded by an intact basement membrane. The percentages of degenerated follicles in situ and after isolation were 3.9 and $6.5 \%$, respectively. In spite of the

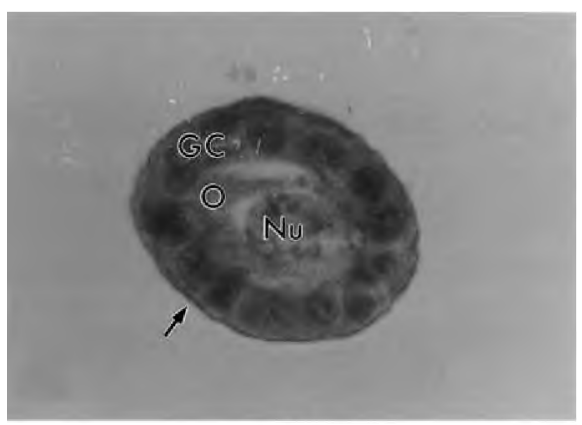

(A)

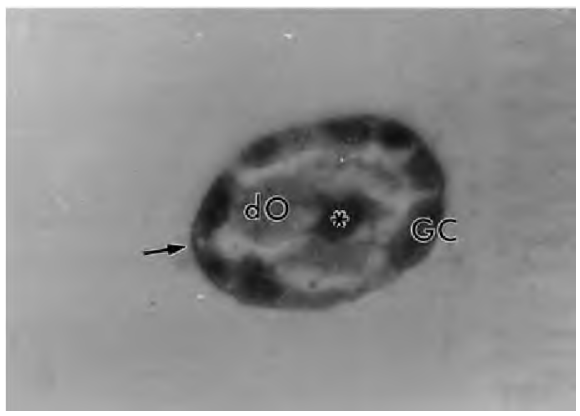

(B)

Fig. 6. Histological sections of (A) a morphologically normal follicle, and (B) a degenerated follicle, after isolation. O: normal oocyte; Nu: nucleus of a normal oocyte, GC: granulosa cells; dO: degenerating oocyte (* marks condensed nucleus). The basement membrane surrounding the follicles is marked by arrow. PAShematoxilin stained $(1100 \times)$. 


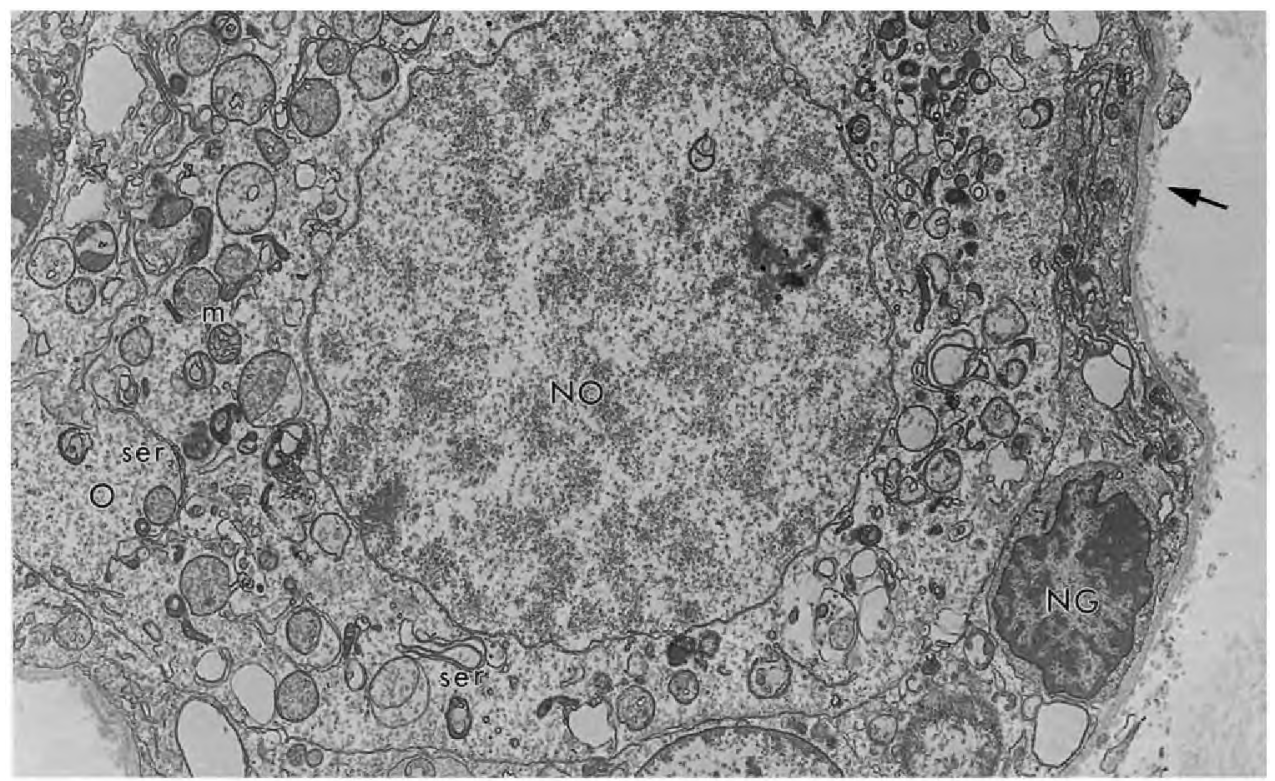

(A)

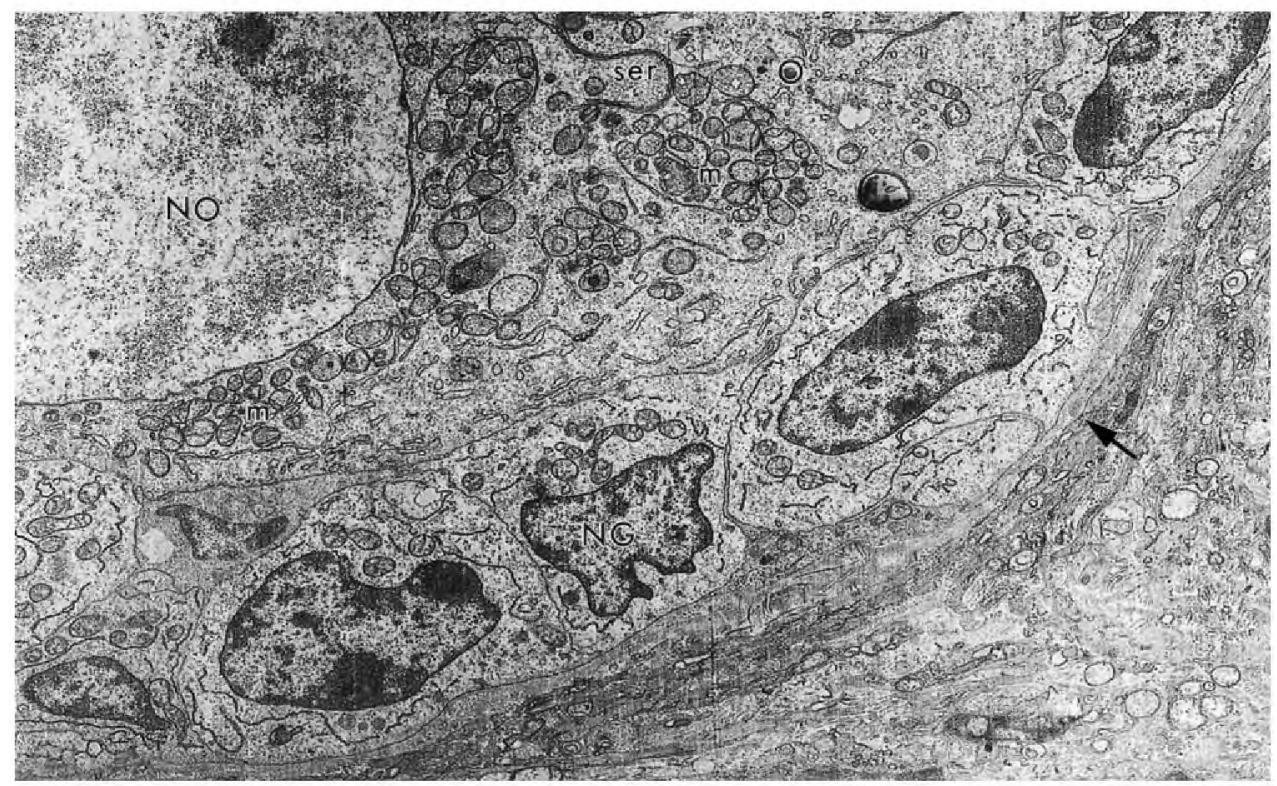

(B)

Fig. 7. Electron micrographs of preantral follicles (A) after mechanical isolation $(5200 \times)$, and (B) in situ $(4200 \times)$. O: oocyte; NO: nucleus of oocyte; NG: nucleus of granulosa cells; m: mitochondria; ser: smooth endoplasmic reticulum; arrow marks the basement membrane. 
numerical difference, the statistical analysis of the number of degenerated follicles after isolation and in situ showed that there was no significant difference $(P=0.2843)$. Retraction of the oocyte or condensation of its nucleus (Fig. 6B) characterized the follicular degeneration most frequently observed, both in situ and after isolation. Granulosa cells were apparently unaffected. These degenerative signals were detected only histologically and not under the inverted microscope.

The transmission electron microscopy analysis of isolated follicles (Fig. 7A) showed that they were ultrastructurally similar to those in situ (Fig. 7B), indicating that they were not affected by the isolation procedure. The oocytes presented a large and well-demarcated nucleus, numerous round mitochondria, a few cisternae of smooth endoplasmic reticulum and Golgi apparatus, and a few vesicles within their cytoplasm. Granulosa cells presented many elongated mitochondria and abundant smooth and rough endoplasmic reticulum and Golgi apparatus. No alterations were observed in the contact between oocyte and granulosa cells in isolated follicles. Granulosa cells and oocyte were close together and the basement membrane was always present surrounding the follicles, both in nontreated ovarian tissue and after mechanical isolation. The ultrastructural analysis revealed that the basement membrane is composed of a compact basal lamina surrounded by a thick layer of collagen fibers.

\section{Discussion}

The results of this study have shown that a large number of Zebu preantral follicles can be isolated using a simple mechanical procedure and that the number obtained is affected by the cut interval chosen for sectioning the ovarian tissue. This effect has already been demonstrated in other species, like caprine [6] and ovine [5]. In the present work, the greatest number of isolated Zebu cow preantral follicles was obtained using the $125 \mu \mathrm{m}$ interval. In goats and sheep, the best results were obtained with the intervals of $75 \mu \mathrm{m}$ [6], and $87.5 \mu \mathrm{m}$ [5], respectively. These results suggest, again, that the most suitable interval for sectioning the ovarian tissue using a tissue chopper varies among species. In the present study, it seems that the use of cut intervals smaller than $125 \mu \mathrm{m}$ may destroy preantral follicles, while the larger intervals may reduce the efficiency of mechanical dissociation of the ovarian fragments with Pasteur pipettes and thus prevent preantral follicle release from the ovarian tissue. Species-specific differences regarding the most suitable cut interval to isolate preantral follicles can be explained by differences in ovarian composition, which can interfere in the cutting process. For example, follicles embedded in a more fibrous stroma can be more difficult to isolated and smaller cut intervals would be necessary.

The present study not only identified the most suitable cut interval to isolate preantral follicles from Zebu ovaries, but also evaluated the quantitative and qualitative effectiveness of this isolation method. To evaluate the quantitative effectiveness of the method, an estimation of the preantral follicle population in Zebu ovaries in situ was performed. The results showed that Zebu ovaries have on average 70,576 preantral follicles $(35,288$ per one-half ovary). A similar number of in situ preantral follicles was reported for European cattle [18] and sheep [19]. Other studies, however, reported lower numbers of preantral follicles in goat [4] and sheep [20] ovaries. It is well-known that besides the species 
differences, preantral follicle populations may be affected by factors such as breed [16], age [18,21], hormone levels and reproductive stage [22], and nutrition [23].

The number of preantral follicles recovered from Zebu ovaries using the $125 \mu \mathrm{m}$ interval was 52,100 (26,050 per one-half ovary). Other researchers isolated a large number of ovarian preantral follicles from European cows [3,15,24], goats [4,6], ewes [2,5], pigs [25], domestic cats [26,27] and nondomestic felids [28,29], rabbits [30], rats [31], mice [32], and humans [33], using mechanical [2-4,15,24,26-29] or enzymatic [25,30-33] procedures. Comparisons between our results and those of other studies are difficult to perform due to species differences, variation in follicle classification, and types of follicles included in the final count. On the other hand, the follicular recovery rate is a good parameter to compare the effectiveness of different isolation methods. In the present study, the recovery rate of preantral follicles was $74 \%$, and is higher than those described for goats $(36 \%, 4)$ and sheep $(27 \%, 2)$. It is important to note that the recovery rate should only be applied using half of the same ovary or at least the contralateral ovary as a control, since the population of the preantral follicle may be affected by other factors, as mentioned above.

Concerning the distribution of the isolated follicles into follicular classes, in the present work, 98.0, 1.6 and $0.4 \%$ of the total isolated follicles were primordial, primary and secondary, respectively. Other studies showed similar results in the isolation of preantral follicles using a tissue chopper [2,4,34]. In contrast, Hulshof et al. [15], using watchmaker's forceps to isolate preantral follicles, observed a lower percentage of isolated primordial follicles $(12.5 \%)$ when compared to primary $(57.2 \%)$ and secondary $(20.7 \%)$ follicles. These authors suggest that it may be due to primordial follicles being tightly embedded in the tunica albuginea [15], and a mild mechanical treatment is not sufficient to isolate these follicles. A large number of primordial follicles was easily isolated from pig ovaries using a combined mechanical and enzymatic method [35], suggesting that an enzymatic treatment of the ovaries may be necessary to isolate this class of preantral follicles. Based on the present work, the use of the tissue chopper proves to be a more powerful method to isolate a great number of primordial follicles without additional enzymatic treatment. Overall, this mechanical method isolated about 79.2, 20.5 and $37.6 \%$, respectively, of the total primordial, primary and secondary follicles present in Zebu cow ovaries.

Before the qualitative evaluation of the isolated follicles could be done, a characterization of the preantral follicles in situ had to be performed. The results showed that the mean diameter of Zebu oocytes and follicles and the mean number of granulosa cells at the equatorial section were similar to those observed in European cows [36-38] in all three developmental stages (i.e. primordial, primary and secondary). Also, our results were similar to those described for humans [39], but different from those described for ewes [40] and goats [41]. In addition, some polyovular follicles could be observed in Zebu cow ovaries. The occurrence of polyovular follicles has been reported in other mammals $[4,35,42,43]$. Although this kind of follicles appears to be normal in different mammalian species, in which they are seen with a variable frequency, their role remains unknown.

In this study, the diameters of the primordial and secondary freshly isolated follicles were lower than those measured in histological sections. For secondary follicles, it was surely due to filtration, which allowed only follicles smaller than $100 \mu \mathrm{m}$ to pass through. For primordial follicles, this difference may be due to the release of the follicles from the 
ovarian stroma. According to Van Wezel and Rodgers [38], primordial follicles show an oblate shape in three dimensions. Once in suspension these follicles probably assume a vertical position, with the poles up and down, making it possible to measure only the smallest diameter. In contrast, in histological sections, we could see the follicles in many positions, and therefore, take the smallest or the largest diameter depending on the follicles orientation.

In reference to the quality of the isolated preantral follicles, in this study, no denuded oocytes were observed, likely given the fact that the basement membrane offers mechanical resistance and protects the follicles from physical damage during isolation, as suggested by Figueiredo et al. [44]. Histochemical and ultrastructural analysis demonstrated that mechanically isolated follicles were surrounded by an intact basement membrane. Similar results were obtained by Figueiredo et al. $[44,45]$ and Lucci et al. [4] using a tissue chopper to isolate bovine and caprine preantral follicles, respectively. In contrast, some studies have described that proteolytic enzymes commonly used for isolating follicles are detrimental to cell membranes [30,46-49]. In vitro culture of enzymatically isolated preantral follicles, which are not surrounded by a basement membrane, shows a spreading of granulosa cells from the oocytes [8,50]. In contrast, this latter occurrence was not observed when mechanically isolated preantral follicles were cultured in vitro [45]. The culture of preantral follicles surrounded by a natural basement membrane has many advantages including preservation of follicular morphology and maintenance of follicular adhesion to extracellular compounds [45]. Thus, the presence of a basement membrane around the isolated follicles is important for further studies of in vitro culture of Zebu preantral follicles.

Furthermore, this study showed that only a few follicles were degenerated in situ (3.9\%), as well as after isolation (6.5\%). The low percentage of degenerated follicles observed in this study coincides with other studies [16,51]. The histological analysis of preantral follicles, in situ and isolated, showed that the degeneration is characterized by oocyte alterations while pycnotic bodies were not observed in granulosa cells. Jorio et al. [51] described that degeneration of oocytes is the mode of atresia most frequently observed in preantral follicles. Although pycnosis of granulosa cells frequently occurs in antral follicles, it is almost absent in preantral follicles. Moreover, in an in vitro study by Braw-Tal and Yossefi [36] it was found that in some preantral follicles the oocyte degenerated or completely disappeared while granulosa cells looked healthy and continued to proliferate, showing that the oocyte is much more sensitive than the granulosa cells.

In this study, the electron microscopy revealed that isolated follicles were ultrastructurally similar to those present in situ. Follicular damage possibly caused by the isolation method was not observed in the present study, contrary to Van Den Hurk et al. [7], who described a poor ultrastructure of the small preantral follicles isolated using a tissue chopper. Small preantral follicles are very sensitive to osmolarity changes and centrifugation (Lucci et al., unpublished data). Therefore, this difference between studies may be due to different methods used to process the isolated follicles for ultrastructural analysis, since the same isolation method was used by both.

In conclusion, this study demonstrated that a large number of preantral follicles can be successfully isolated from Zebu cow ovaries, with a high recovery rate and a low rate of follicular degeneration, using the described mechanical method. Also, this study shows for 
the first time an estimation of the preantral follicle population in Zebu cow ovaries. The obtained data revealed that, despite the differences between B. taurus and B. indicus, Zebu preantral follicles seemed to be very similar to European cow follicles in number and measurement characteristics.

\section{Acknowledgements}

In memory of A.R. de Bem. The authors thank N. Durrett for the English correction of the manuscript. This research was supported by $\mathrm{CNPq}$.

\section{References}

[1] Saumande J. La folliculogénèse chez les ruminants. Rec Méd Vét 1991;167:205-18.

[2] Amorim CA, Rodrigues APR, Lucci CM, Figueiredo JR, Gonçalves PBD. Effect of sectioning on the number of isolated ovine preantral follicles. Small Rum Res 2000;37:269-77.

[3] Figueiredo JR, Hulshof SCJ, Van Den Hurk R, Ectors FJ, Fontes RS, Nusgens B, et al. Development of a combined new mechanical and enzymatic method for the isolation of intact preantral follicles from fetal, calf and adult bovine ovaries. Theriogenology 1993;40:789-99.

[4] Lucci CM, Amorim CA, Rodrigues APR, Figueiredo JR, Báo SN, Silva JR, et al. Study of preantral follicular population in situ and after mechanical isolation from undefined breed type goats at different reproductive stages. Anim Reprod Sci 1999;56:223-36.

[5] Amorim CA, Lucci CM, Rodrigues APR, Carvalho FCA, Figueiredo JR, Rondina D, et al. Quntitative and qualitative analysis of the effectiveness of a mechanical method for the isolation of preantral follicles from ovine ovaries. Theriogenology 2000;53:1251-62.

[6] Lucci CM, Amorim CA, Báo SN, Figueiredo JR, Rodrigues APR, Silva JRV, et al. Effect of the interval of serial sections of ovarian tissue in the tissue chopper on the number of isolated caprine preantral follicles. Anim Reprod Sci 1999;56:39-49.

[7] Van Den Hurk R, Spek ER, Hage WJ, Fair T, Ralph JH, Schotanus K. Ultrastruscture and viability of isolated bovine preantral follicles. Human Reprod Update 1998;4:833-41.

[8] Eppig JJ. Growth and development of mammalian oocytes in vitro. Arch Pathol Lab Med 1992;116:37982.

[9] Barros CM, Figueiredo RA, Pinheiro OL. Estro, ovulação e dinâmica folicular em zebuínos. Rev Bras Reprod Anim 1995;19:9-22.

[10] Basile JR, Megale S, Vale Filho VR, Garcia OS, Silva NQ. Ocorrência de alterações do ovário em vacas azebuadas abatidas em matadouro. Rev Bras Reprod Anim 1988;12:147-61.

[11] Chenoweth PJ. Aspects of reproduction in female Bos indicus cattle-a review. Aust Vet J 1994;71:422-6.

[12] Figueiredo RA, Barros CM, Rocha GP, Papa FO. Prevalência de duas ondas de crescimento folicular ovariano em vacas da raça Nelore. Rev Bras Reprod Anim 1995;19:200-11.

[13] Maclellan IJ, Whyte TR, Murray A, Fitzpatrick LA, Earl CR, Aspden WJ, et al. Superstimulation of ovarian follicular growth with FSH, oocyte recovery and embryo production from Zebu (Bos indicus) calves: effects of treatment with a GnRH agonist or antagonist. Theriogenology 1998;49:1317-29.

[14] Vetromila MAM, Ferreira AM, de Sá WF. Observações qualitativas e quantitativas na população de folículos de bovinos mestiços Holandês/Zebu. Rev Bras Reprod Anim 1995;19:165-72.

[15] Hulshof SCJ, Figueiredo JR, Beckers JF, Bevers MM, Van Den Hurk R. Isolation and characterization of preantral follicles from foetal bovine ovaries. Vet Quart 1994;16:78-80.

[16] Cahill LP, Mariana JC, Mauléon P. Total follicular populations in ewes of high and low ovulation rates. J Reprod Fertil 1979;55:27-36.

[17] Gougeon A, Chainy GBN. Morphometric studies of small follicles in ovaries of women at different ages. J Reprod Fertil 1987;81:433-42. 
[18] Erickson BH. Development and senescence of the postnatal bovine ovary. J Anim Sci 1966;25:800-5.

[19] Land RB. Number of oocytes present at birth in the ovaries of pure and Finnish Landrace cross Blackface and Welsh sheep. J Reprod Fertil 1970;21:517-21.

[20] Driancourt MA, Cahill LP, Bindon BM. Ovarian follicular populations and preovulatory enlargement in booroola and control merino ewes. J Reprod Fertil 1985;73:93-107.

[21] Erickson BH. Development and radio-response of the prenatal bovine ovary. J Reprod Fertil 1966;10:97105.

[22] Erickson BH, Reynolds RA, Murphree RL. Ovarian characteristics and reproductive performance of the aged cow. Biol Reprod 1976;15:555-60.

[23] Scaramuzzi RJ, Adams NR, Baird DT, Campbell BK, Downing JA, Findlay JK, et al. A model for follicle selection and the determination of ovulation rate in the ewe. Reprod Fertil Dev 1993;5:459-78.

[24] Nuttinck F, Mermillod P, Massip A, Dessy F. Characterization of in vitro growth of bovine preantral ovarian follicles: a preliminary study. Theriogenology 1993;39:811-21.

[25] Lazzari G, Galli C, Moor RM. Centrifugal elutriation of porcine oocytes isolated from the ovaries of newborn piglets. Anal Biochem 1992;200:31-5.

[26] Jewgenow K, Göritz F. The recovery of preantral follicles from ovaries of domestic cats and their characterization before and after culture. Anim Reprod Sci 1995;39:285-97.

[27] Jewgenow K, Pitra C. Hormone-controlled culture of secondary follicles of domestic cats. Theriogenology 1993;39:527-35.

[28] Jewgenow K, Blottner S, Lengwinat T, Meyer HHD. New methods for gamete rescue from gonads of nondomestic felids. J Reprod Fertil 1997;51(Suppl):33-9.

[29] Jewgenow K, Stolte M. Isolation of preantral follicles from nondomestic cats-viability and ultrastructural investigations. Anim Reprod Sci 1996;44:183-93.

[30] Nicosia SV, Evangelista I, Batta SK. Ra, Rabbit ovarian follicles. Part I. Isolation technique and characterization at different stages of development. Biol Reprod 1975;13:423 47.

[31] Daniel SAJ, Armstrong DT, Gore-Langton RE. Growth and development of rat oocytes in vitro. Gamete Res 1989;24:109-21.

[32] Eppig JJ, Downs SM. The effect of hypoxanthine on mouse oocyte growth and development in vitro: maintenance of meiotic arrest and gonadotropin-induced oocyte maturation. Dev Biol 1987;119:313-21.

[33] Roy SK, Treacy BJ. Isolation and long-term culture of human preantral follicles. Fertil Steril 1993;59:783-90.

[34] Rodrigues APR, Amorim CA, Lucci CM, Figueiredo JR, Gonçalves PBD, Bem AR. Isolamento mecânico de folículos ovarianos pré-antrais em cabras. Ciência Rural 1998;28:477-82.

[35] Greenwald GS, Moor RM. Isolation and preliminary characterization of pig primordial follicles. J Reprod Fertil 1989;87:561-71.

[36] Braw-Tal R, Yossefi S. Studies in vivo and in vitro on the initiation of follicle growth in the bovine ovary. J Reprod Fertil 1997;109:165-71.

[37] Hyttel P, Fair T, Callensen H, Greve T. Oocyte growth, capacitation and final maturation in cattle Theriogenology 1997;47:23-32.

[38] Van Wezel I, Rodgers RJ. Morphological characterization of bovine primordial follicles and their environment in vivo. Biol Reprod 1996;55:1003-11.

[39] Lintern-Moore S, Peters H, Moore GPM, Faber M. Follicular development in the infant human ovary. J Reprod Fertil 1974;39:53-64.

[40] Lundy T, Smith P, O'connell A, Hudson NL, Mcnatty KP. Population of granulosa cells in small follicles of the sheep ovary. J Reprod Fertil 1999;115:251-62.

[41] Lucci CM, Silva JRV, Carvalho FCA, Figueiredo JR, Báo SN. Light microscopical and ultrastructural characterization of goat preantral follicles. Small Rum Res 2001;41:61-9.

[42] Hadek R. Morphological and histochemical study in the ovary of the sheep. Am J Vet Res 1958;19:87381.

[43] McDougall K, Hay MA, Goodrowe KL, Gartley CJ, King WA. Changes in the number of follicles and of oocytes in ovaries of prepubertal, peripubertal and mature bitches. J Reprod Fertil 1997;51(Suppl):25-31.

[44] Figueiredo JR, Hulshof SCJ, Thiry M, Van Den Hurk R, Bevers MM, Nusgens B, et al. Extracellular matrix proteins and basement membrane: their identification in bovine ovaries and significance for the attachment of cultured preantral follicles. Theriogenology 1995;43:845-58. 
[45] Figueiredo JR, Hulshof SCJ, Van Den Hurk R, Nusgens B, Bevers MM, Ectors FJ, et al. Preservation of oocyte and granulosa cell morphology in bovine preantral follicles cultured in vitro. Theriogenology 1994; $41: 1333-46$.

[46] Cavanaugh DJ, Berndt WO, Smith TE. Dissociation of heart cells by collagenase. Nature 1963;200:261-2.

[47] Grob HS. Enzymatic dissection of the mammalian ovary. Science 1964;146:73-4.

[48] Kono T. Destruction of insulin effector system of adipose tissue cells by proteolytic enzymes. J Biol Chem 1969;244:1772-8.

[49] Post G. Adsorption and activity of enzymes at the cell surface. Tissue dissociation with proteolytic enzymes. Exp Cell Res 1971;65:359-67.

[50] Maresh GA, Timmons TM, Dunbar BS. Effects of extracellular matrix on the expression on specific ovarian proteins. Biol Reprod 1990;43:965-76.

[51] Jorio A, Mariana JC, Lahlou-Kassi A. Development of the population of ovarian follicles during the prepubertal period in D'man and Timahdite sheep. Anim Reprod Sci 1991;26:239-50. 